\title{
Pengaruh Lingkungan Kerja Non Fisik Dan Komunikasi Terhadap Kinerja Karyawan Pada PT. Bangkit Maju Bersama Di Jakarta
}

\author{
N. Lilis Suryani \\ Dosen Fakultas Ekonomi Universitas Pamulang \\ Email : dosen00437@unpam.ac.id
}

\begin{abstract}
ABSTRAK
Penelitian ini bertujuan untuk mengetahui pengaruh lingkungan kerja non fisik dan komunikasi terhadap kinerja karyawan pada PT. Bangkit Maju Bersama di Jakarta.

Metode yang digunakan adalah explanatory research, dan pengujian hipotesis. Dengan teknik survey, menyebar kuesioner dengan skala Likert. Teknik penentuan memakai sampling jenuh dengan 60 responden.

Teknik analisis data yang digunakan analisis deskriptif dan analisis verifikatif yaitu: Uji Validitas, Uji Reliabilitas, Uji Asumsi Klasik, Analisis Regresi Berganda, Analisis Koefisien Korelasi, Analisis Koefisien Determinasi $\left(\mathrm{R}^{2}\right)$ dan Pengujian Hipotesis dengan Uji Parsial (uji t) dan Uji Simultan (uji F).

Hasil Pengujian dan analisisnya adalah sebagai berikut:

1. Terdapat pengaruh positif dan signifikan antara lingkungan kerja non fisik terhadap kinerja karyawan, dengan korelasi positif 0,652 dengan tingkat hubungan yang kuat dan kontribusi pengaruh sebesar 42,5\%. Uji hipotesis $\rho$ value $0,000<0,05$.

2. Terdapat pengaruh positif dan signifikan antara komunikasi terhadap kinerja karyawan, dengan korelasi positif 0,637 dengan tingkat hubungan yang kuat dan kontribusi pengaruh sebesar 40,5\%. Uji hipotesis diperoleh $\rho$ value $0,000<0,05$.

3. Terdapat pengaruh positif dan signifikan antara lingkungan kerja non fisik dan komunikasi secara simultan terhadap kinerja karyawan dengan korelasi positif 0,723 dengan tingkat hubungan yang kuat dan kontribusi pengaruh sebesar 52,3\%. Uji hipotesis diperoleh $\rho$ value $0,000<0,05$.
\end{abstract}

\section{Kata Kunci : Lingkungan kerja non fisik, Komunikasi dan Kinerja karyawan}




\section{PENDAHULUAN}

\section{A. Latar Belakang Masalah}

Manajemen sumberdaya manusia sangat berperan penting bagi perusahaan agar memberikan hasil maksimal selain itu juga akan memiliki profesionalitas terbaik yang dapat diandalkan untuk mencapai tujuan dan sasaran perusahaan yaitu mendapatkan keuntungan yang maksimal.

Sebagai kunci pokok, sumber daya manusia akan menentukan keberhasilan pelaksanaan kegiatan perusahaan. Tuntutan perusahaan untuk memperoleh, mengembangkan dan mempertahankan sumber daya menusia yang berkualitas semakin mendesak sesuai dengan dinamika lingkungan yang selalu berubah. Dalam bekerja lingkungan kerja non fisik sangat mendukung untuk memberikan kenyamanan karyawan,lingkungan kerja non fisik merupakan salah satu hal yang penting dalam meningkatkan efektivitas kerja karyawan. Karena lingkungan kerja fisik maupun lingkungan kerja non fisik dapat mempengaruhi physiology dan psychologist karyawan dalam bekerja.

Dalam hal ini komunikasi sangat berhubungan terhadap manajemen organisasi dalam menciptakan pola kerja yang konsisten terhadap situasi kerja yang nyaman. Jika komunikasi yang di lakukan oleh atasan kepada bawahannya tidak berjalan secara optimal karyawan akan mengalami kesulitan memahami apa yang menjadi keinginan atasan sehingga kinerja yang di lakukan para karyawan tidak terkontrol dengan baik. Bukan hanya komunikasi antara atasan dan bawahan saja yang berhubungan dengan kinerja karyawan namun komunikasi yang dilakukan antara karyawan dengan karyawan yang lain juga masih belum berjalan dengan baik, masih ada karyawan yang berkomunikasi dengan karyawan lainnya tidak memberikan informasi yang jelas dan lengkap sehingga berhubungan terhadap sikap para karyawan tersebut. Dengan kurang efektifnya komunikasi organisasi yang di lakukan baik dari atasan kepada bawahan atau antara karyawan dengan karyawan yang lainnya.

Menurut Malayu Hasibuan (2017:139), "Kinerja adalah suatu hasil kerja yang dicapai seseorang dalam melaksanakan tugas-tugas yang dibebankan kepadanya yang didasarkan kepada kecakapan, pengalaman, kesungguhan waktu". Kinerja adalah poin penting dalam kemajuan perusahaan, semakin meningkatnya kinerja karyawan maka akan semakin penting dalam kemajuan perusahaan, semakin meningkatnya kinerja karyawan maka akan semakin cepat tercapainya tujuan perusahaan. Dengan meningkatnya kinerja karyawan maka perusahaan akan memperoleh keuntungan, oleh sebab itu perusahaan perlu terus menjaga agar kinerja karyawan dapat meingkat dari waktu ke waktu.

Jika karyawan yang dipekerjakan tidak memiliki kinerja yang baik yang dibutuhkan perusahaan, maka perusahaan tidak akan mencapai target yang 
sudah ditetapkan, dan merugikan perusahaan itu sendiri. Oleh sebab itu, dalam penarikan, seleksi, penempatan karyawan harus berdasarkan azas the right man in the right place, and the right man in the right job, yang artinya karyawan perlu ditempatkan pada pekerjaan yang sesuai dengan kemampuannya sangatlah penting untuk mencapai tujuan perusahaan dan kinerja karyawan yang lebih optimal.

\begin{tabular}{|c|c|c|c|c|}
\hline \multirow{2}{*}{$\begin{array}{c}\text { Jenis } \\
\text { Rumah }\end{array}$} & \multicolumn{2}{|c|}{2016} & \multicolumn{2}{c|}{2017} \\
\cline { 2 - 5 } & Target & Realisasi & Target & Realisasi \\
\hline Baru & 250 & 205 & 250 & 170 \\
\hline Rekondisi & 250 & 211 & 250 & 198 \\
\hline Jumlah & 500 & 416 & 500 & 368 \\
\hline
\end{tabular}

PT. Bangkit Maju Bersama adalah salah satu perusahaan yang bergerak dibidang pengembang perumahan baik rumah baru maupun rumah rekondisi.

Sesuai hasil temuan awal peneliti, peneliti menemukan tingginya tingkat absensi karyawan di PT. Bangkit Maju Bersama dari Januari sampai dengan Desember 2017. Hal ini bila tidak segera dilakukan tindakan maka akan berdampak buruk bagi pencapaaian tujuan perusahaan, untuk itu pemimpin perusahaan harus lebih memperhatikan pemberian komunikasi yang ada di perusahaan agar karyawan dapat kembali bersemangat bekerja dan menunjukan kinerja yang baik dalam membantu tercapainya tujuan perusahaan.

Dari data diatas menunjukan bahwa terjadi penurunan pembelian rumah dari tahun ke tahun, pencapaian target masih kurang memuaskan.. Mengingat bahwa lingkungan kerja non fisik dan komunikasi merupakan salah satu faktor yang juga penting dalam meningkatkan kinerja karyawan, maka penulis tertarik untuk melakukan penelitian lebih dalam dengan judul "Pengaruh Lingkungan kerja non fisik Terhadap Kinerja karyawan Pada PT. Bangkit Maju Bersama".

\section{B. Rumusan Masalah}

Berdasarkan identifikasi dan pembatasan masalah di atas, maka untuk mencegah terjadinya kerancuan dalam pembahasan, perlu penulis berikan suatu perumusan masalah sebagai berikut :

1. Bagaimana pengaruh secara parsial antara lingkungan kerja non fisik terhadap kinerja karyawan pada PT. Bangkit Maju Bersama?

2. Bagaimana pengaruh secara parsial antara komunikasi terhadap kinerja karyawan pada PT. Bangkit Maju Bersama?

3. Bagaimana pengaruh secara simultan antara lingkungan kerja non fisik dan komunikasi terhadap kinerja karyawan pada PT. Bangkit Maju Bersama?

\section{Pembatasan Masalah}

Agar lebih mudah di pahami dan dimengerti, peneliti membatasi hanya yang diteliti, yaitu mengenai lingkungan kerja non fisik dan komunikasi dan pengaruhnya terhadap kinerja karyawan pada PT. Bangkit Maju Bersama, dengan cara melakukan penyebaran kuesioner kepada karyawan di PT. Bangkit Maju Bersama.

\section{Tujuan Penelitian}

Tujuan penelitian ini adalah : 
1. Untuk mengetahui pengaruh secara parsial antara lingkungan kerja non fisik terhadap kinerja karyawan pada PT. Bangkit Maju Bersama.

2. Untuk mengetahui pengaruh secara parsial antara komunikasi terhadap kinerja karyawan pada PT. Bangkit Maju Bersama.

3. Untuk mengetahui seberapa besar pengaruh secara simultan antara lingkungan kerja non fisik dan komunikasi terhadap kinerja karyawan pada PT. Bangkit Maju Bersama.

\section{E. Manfaat Penelitian}

1. Manfaat Teoritis

Dari penelitian ini diharapkan dapat menambah wawasan, dalam kajian menajemen pemasaran dengan riset di lapangan, memberikan informasi bagi pembaca sehingga dapat dijadikan sebagai bahan referensi bagi yang memerlukan.

2. Manfaat Praktis

Dari hasil penelitian ini diharapkan dapat memberikan masukan yang positif, maupun referensi kepada PT. Bangkit Maju Bersama sebagai pertimbangan dalam pengambilan keputusan untuk proses pengembangan sistem (improvement) dan perencanaan strategis dalam menghadapi persaingan usaha yang semakin ketat.

\section{TINJAUAN PUSTAKA}

\section{A. Lingkungan Kerja Non Fisik}

Menurut Sadarmayanti (2011:31) Lingkungan kerja non fisik adalah semua keadaan yang terjadi yang berkaitan dengan hubungan kerja, baik hubungan dengan atasan maupun hubungan sesama rekan kerja, ataupun hubungan dengan bawahan.

\section{B. Komunikasi}

Menurut Himstreet dan Baty dalam Djoko Purwanto (2011:4) komunikasi adalah suatu proses pertukaran informasi antar individu melalui suatu sistem yang biasa (lazim), baik dengan simbol, sinyal-sinyal, maupun tindakan atau prilaku.

\section{Kinerja karyawan.}

Menurut Mangkunegara (2015:9) Kinerja karyawan adalah hasil kerja secara kulalitas dan kuantitas yang dicapai oleh seorang karyawan dalam melaksanakan tugasnya.

\section{Kerangka Berpikir}

Menurut Sugiyono (2017) kerangka berpikir adalah sintesa yang mencerminkan keterkaitan antara variabel yang diteliti dan merupakan tuntunan untuk memecahkan masalah penelitian serta merumuskan hipotesis penelitian yang berbentuk bagan alur yang dilengkapi penjelasan kualitatif. Lebih lanjut Sugiyono (2017) menjelaskan "Seorang peneliti harus menguasai teoriteori ilmiah sebagai dasar menyusun kerangka pemikiran yang membuahkan hipotesis". Lingkungan kerja non fisik memiliki peran penting dalam sumber daya manusia. Lingkungan kerja non fisik adalah semua keadaan yang terjadi yangberkaitan dengan hubungan kerja, baik hubungan dengan atasan maupun hubungan dengan bawahan sesama rekan kerja, 
ataupun hubungan dengan bawahan (Sedamayanti, 2011:46).

Demikian pula komunikasi merupakan faktor yang juga penting dalam meningkatkan kinerja karyawan. Komunikasi adalah suatu proses pemindahan pengertian dalam bentuk gagasan atau informasi dari seseorang ke orang lain.
Kinerja sebagai tolok ukur pencapaian tujuan organisasi menjadi penting diperhatikan dalam organisasi.

Berdasarkan pertimbangan data tersebut, penulis membuat model penelitian dengan variabel lingkungan kerja non fisik dan komunikasi yang peneliti anggap dapat mempengaruhi kinerja

Adapun kerangka berpikir sebagai berikut :

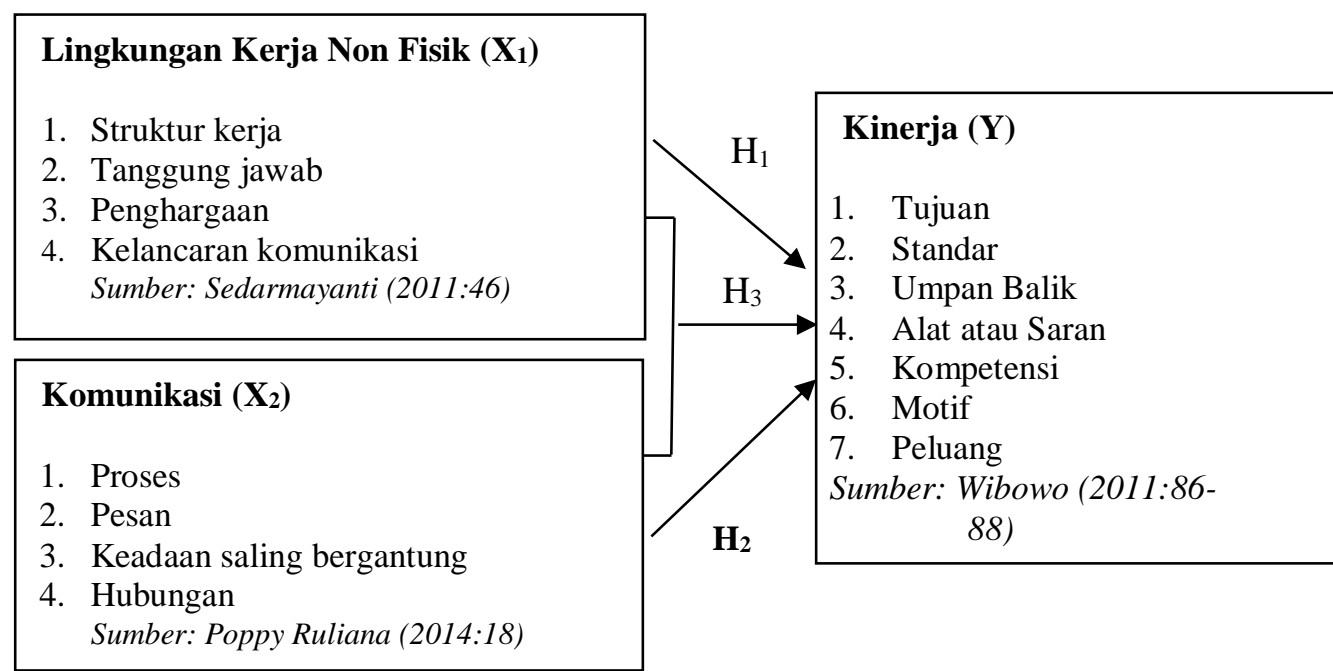

Gambar 1. Kerangka Berfikir

\section{E. Hipotesis Penelitian}

Menurut Sugiyono (2017) hipotesis merupakan jawaban sementara terhadap rumusan masalah. Karena sifatnya masih sementara, maka perlu dibuktikan kebenarannya melalui data empirik yang terkumpul.

Adapun Hipotesis yang penulis ajukan adalah sebagai berikut:

H1 : Diduga terdapat pengaruh positif dan signifikan antara lingkungan kerja non fisik terhadap kinerja karyawan pada PT. Bangkit Maju Bersama.
$\mathrm{H} 2$ : Diduga terdapat pengaruh positif dan signifikan antara komunikasi terhadap kinerja karyawan pada PT. Bangkit Maju Bersama.

H3 : Diduga terdapat pengaruh positif dan signifikan antara lingkungan kerja non fisik dan komunikasi secara bersama-sama karyawan terhadap kinerja karyawan pada PT. Bangkit Maju Bersama. 
METODOLOGI PENELITIAN

A. Tempat dan Waktu Penelitian

1. Tempat Penelitian

Menurut

Sugiyono

(2017:13) tempat penelitian merupakan sasaran ilmiah untuk mendapatkan data dengan tujuan dan kegunaan tertentu tentang sesuatu hal yang objektif. Penulis mengadakan penelitian pada PT. Bangkit Maju Bersama dengan alamat Jl. Palem Aren VIII. No.31. Palem Semi, Karawaci Tangerang. Telp. 021-55796185/021-55796089.

\section{Waktu Penelitian}

Penelitian

ini

dilaksanakan selama MaretMei 2019. Adapun penelitian dilakukan secara bertahap disesuaikan dengan tingkat kebutuhan penulis.

\section{Jenis Penelitian}

Jenis penelitian ini adalah asosiatif, menurut Sugiyono (2017) yaitu penelitian yang bertujuan untuk mengetahui pengaruh atau hubungan antara dua variabel atau lebih. Dengan demikian penelitian asosiatif ini dapat dibangun suatu teori yang berfungsi untuk menjelaskan, meramalkan dan mengontrol suatu gejala

\section{B. Populasi dan Sampel}

\section{Populasi}

Populasi merupakan sekumpulan objek yang ditentukan melalui suatu kriteria tertentu yang akan dikategorikan ke dalam objek yang akan diteliti. Menurut Sugiyono (2017) populasi adalah jumlah wilayah generalisasi yang terdiri atas obyek atau subyek yang mempunyai kualitas dan karakteristik yang ditetapkan oleh peneliti dan kemudian ditarik kesimpulannya. Adapun populasi dalam penelitian ini adalah karyawan PT. Bangkit Maju Bersama.

\section{Sampel}

Menurut Sugiyono (2017) sampel adalah jumlah dan karakteristik yang dimiliki oleh populasi tersebut. Sedangkan menurut Suharsini Arikunto (2010) sampel adalah sebagian atau wakil populasi yang diteliti. Dalam pengambilan sampel dapat menggunakan sampling jenuh dimana menurut Sugiyono (2017) sampling jenuh adalah teknik penentuan sampel bila semua anggota populasi digunakan sebagai sampel. Dalam penelitian ini yang dijadikan sampel adalah orang yang mewakili perusahaannya yang menjadi pelanggan PT. Bangkit Maju Bersama, dalam hal ini berjumlah 60 orang.

\section{Teknik Penentuan Data}

Pengumpulan data merupakan upaya untuk mendapatkan informasi yang akan digunakan dalam pengukuran variabel. Menurut Sugiyono (2017) metode pengumpulan data adalah cara ilmiah utuk mendapatkan data yang valid dengan tujuan dapat dibuktikan, dikembangkan suatu pengetahuan sehingga dapat digunakan memecahkan dan mengantisipasi masalah. 


\section{Data Primer.}

Menurut Sugiyono (2017) data primer adalah sumber data yang langsung memberikan data kepada pengumpul data". Dalam penelitian ini dilakukan dengan cara:

a. Observasi, yaitu pengamatan langsung terhadap Perusahaan dimana pengamatan terbatas pada pokok permasalahan sehingga perhatian lebih fokus kepada data (riil) dan relevan.

b. Menyebar Kuesioner, yaitu membagikan berupa pertanyaan dengan jawaban mengacu pada skala likert.

c. Studi Kepustakaan, yaitu kajian teoritis dan referensi lain yang berkaitan judul penelitian dengan mencari landasan teoritis yang berhubungan dengan judul penelitian, buku serta jurnal yang relevan.

\section{Data Sekunder}

Data sekunder adalah data yang diperoleh secara tidak langsung melalui media perantara yang diperoleh dan dicatat pihak lain. Menurut Sugiyono (2017) "Data sekunder adalah sumber data yang tidak langsung yang memberikan data kepada pengumpul data, misalnya orang lain atau dokumen". Data sekunder dalam penelitian ini antara lain mencakup data historis perusahaan, lingkungan kerja non fisik, komunikasi dan jumlah karyawan perusahaan.

\section{Metode Pengumpulan Data}

\section{Kuesioner}

Dalam penelitian ini untuk mendapatkan data primer kuantitatif, penulis menghubungi responden yaitu karyawan di PT. Bangkit Maju Bersama.

\section{Studi Pustaka.}

Untuk medapatkan data sekunder penulis melakukan dengan cara penelaahan terhadap literature berupa buku pemasaran dan publikasi serta bahan-bahan yang berhubungan dengan masalah yang berkaitan dengan penelitian ini.

\section{E. Metode Analisis Data}

Metode analisis data yang digunakan dalam penelitan ini adalah:

\section{Uji Instrumen Penelitian} a. Uji Validitas

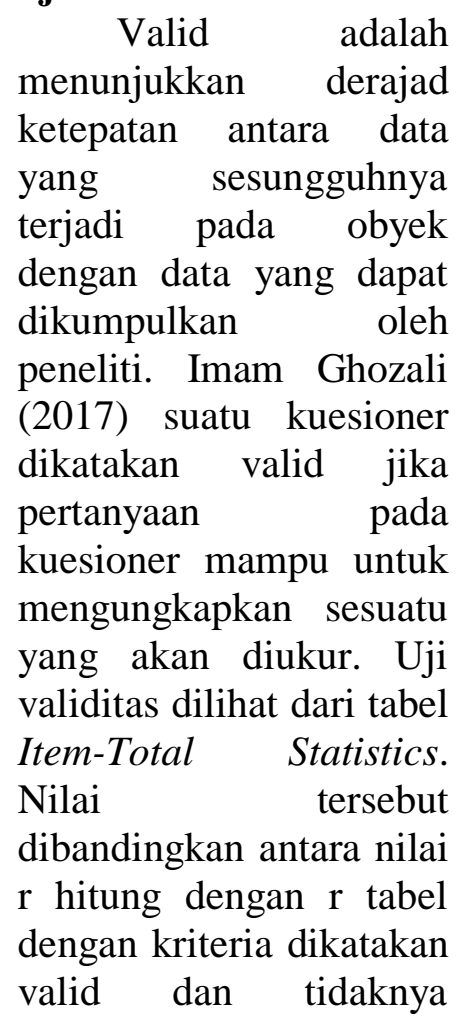


menurut Imam Ghozali (2017) yaitu:

1). Jika $r$ hitung $>r$ tabel, maka instrumen valid,

2). Jika $r$ hitung < r tabel, maka instrumen tidak valid.

b. Uji Reliabilitas

\begin{tabular}{lr}
\multicolumn{1}{c}{ Menurut } & Imam \\
Ghozali & $(2017)$ \\
reliabilitas & merupakan \\
alat untuk & menguj \\
kekonsistenan & jawaban \\
responden & ata
\end{tabular} pertanyaan di kuesioner. Suatu kuesioner dikatakan reliabel jika jawaban seseorang terhadap pertanyaan adalah konsisten atau stabil dari waktu ke waktu. Kriteria yang digunakan apabila suatu alat ukur memberikan hasil yang stabil, maka disebut alat ukur itu handal. Hasil ukur itu diterjemahkan dengan koefisien keandalan yaitu derajat kemampuan alat ukur mengukur perbedaan-perbedaan

individu yang ada. Keandalan itu perlu, sebab data yang tidak andal atau bias tidak dapat diolah lebih lanjut karena akan menghasilkan

kesimpulan yang bias. Pengukuran dilakukan sekali dan reliabilitas dengan uji statistik Cronbach Alpha. Dalam pengukurannya one shot akan dilakukan dengan analisis Cronbach's

Alpha. Imam Ghozali (2017)

mengklasifikasikan nilai

Cronbach's Alpha

sebagai berikut:

Tabel 1. Pedoman Interval Uji

Reliabilitas

\begin{tabular}{|c|c|}
\hline $\begin{array}{c}\text { Interval Nilai } \\
\text { Cronbach's Alpha }\end{array}$ & Kriteria \\
\hline $0,00-0,20$ & Kurang Reliabel \\
\hline $0,21-0,40$ & Agak Reliabel \\
\hline $0,41-0,60$ & Cukup Reliabel \\
\hline $0,61-0,80$ & Reliabel \\
\hline $0,81-1,00$ & Sangat Reliabel \\
\hline
\end{tabular}

2. Uji Kelayakan Data (Uji Asumsi Klasik)

Uji asumsi klasik digunakan untuk mengetahui ketepatan sebuah data. Menurut Singgih Santoso (2015) "Sebuah model regresi akan digunakan untuk melakukan peramalan, sebuah model yang baik adalah model dengan kesalahan peramalan yang seminimal mungkin. Karena itu, sebuah model sebelum digunakan seharusnya memenuhi beberapa asumsi, yang biasa disebut asumsi klasik". Dalam penelitian ini uji asumsi klasik yang digunakan adalah meliputi: Uji Normalitas, Uji Multikolinearitas, Uji Autokorelasi, dan Uji Heterokedastisitas

\section{a. Uji Normalitas}

Uji normalitas digunakan untuk menguji apakah dalam sebuah model regresi, variabel dependen, variabel independen mempunyai distribusi normal atau tidak. Normalitas dapat dideteksi 
dengan melihat penyebaran pada (titik) pada sumbu diagonal pada grafik. Adapun menurut Ghozali (2017:164) dasar pengambilan keputusan adalah sebagai berikut:

1) Jika data menyebar disekitar garis diagonal dan mengikuti arah garis diagonal, maka model regresi memenuhi normalitas.

2) Jika data menyebar jauh dari garis diagonal dan tidak mengikuti arah garis diagonal, maka model regresi tidak memenuhi normalitas

\section{b. Uji Multikolinieritas}

Uji Multikoliniearitas ini bertujuan untuk menguji apakah pada model regresi ditemukan adanya korelasi antar variabel independen. Menurut Ghozali (2017), Uji multikolinearitas bertujuan untuk menguji apakah pada model regresi ditemukan adanya korelasi antar variabel bebas. Model regresi yang baik seharusnya tidak terjadi korelasi di antara variabel independen. Jika variabel independen saling berkorelasi, maka variabel-variabel ini tidak ortogonal. Untuk mendeteksi ada tidaknya multikoliniearitas dalam model regresi dapat dilihat dari tolerance value atau Variance Inflation Factor (VIF) dengan ketentuan sebagai berikut:
1) Jika nilai nilai tolerance lebih > dari 0.1 dan nilai variance inflation factor (VIF) < dari 10, maka tidak terjadi multikolinieritas.

2) Jika nilai nilai tolerance lebih < dari 0.1 dan nilai variance inflation factor (VIF) > dari 10, maka terjadi multikolinieritas.

\section{c. Uji Autokorelasi}

Uji autokorelasi digunakan untuk mengetahui ada atau tidaknya penyimpangan asumsi klasik autokorelasi. Menurut Imam Ghozali (2017) Uji autokorelasi bertujuan menguji apakah dalam model regresi liner ada korelasi antar kesalahan pengganggu pada periode $\mathrm{t}$ dengan kesalahan pengganggu pada periode $\mathrm{t}$ 1. Model regresi yang baik adalah regresi yang bebas dari autokorelasi. Cara yang dapat digunakan untuk menditeksi ada atau tidaknya autokorelasi dalam penelitian ini yaitu dengan uji Durbin-Watson Test dengan berpedoman pada kriteria pedoman sebagai berikut:

Tabel 2. Pedoman Uji Autokorelasi Dengan Memakai Uji Darbin-Watson

\begin{tabular}{|c|c|}
\hline Kriteria & Keterangan \\
\hline$<1,000$ & Ada autokorelasi \\
\hline $1,100-1,540$ & Tanpa kesimpulan \\
\hline $1,550-2,460$ & Tidak ada autokorelasi \\
\hline $2,460-2,900$ & Tanpa kesimpulan \\
\hline$>2,900$ & Ada autokorelasi \\
\hline \multicolumn{2}{|c|}{ Sumber : Algifari, $(2011)}$.
\end{tabular}

d. Uji Heteroskesdastisitas Menurut Imam Ghozali (2017) berpendapat 
bahwa

"Uji

heteroskedastisitas bertujuan untuk mengetahui apakah dalam model regresi terjadi ketidaksamaan varian dari suatu residual pengamatan ke pengamatan lain". Salah satu cara uji heteroskesdastisitas, dapat melihat grafik scatter plot dengan ketentuan sebagai berikut:

1) Jika penyebaran data pada scatter plot tidak teratur dan tidak membentuk pola tertentu (naik turun, mengelompok menjadi satu) maka dapat disimpulkan tidak terjadi problem

Heteroskedastisitas.

2) Jika penyebaran data pada scatter plot teratur dan membentuk pola tertentu (naik turun, mengelompok menjadi satu) maka dapat disimpulkan terjadi problem

Heteroskedastisitas.

\section{Analisis Deskriptif Dan} Verifikatif

\section{a. Analisis Deskriptif}

$$
\text { Analisis dilakukan }
$$
dengan melihat frekuensi dari pilihan opsi oleh responden yang disediakan pada setiap pertanyaan kuesioner. Dalam penelitian ini, pembobotan data, peneliti menggunakan skala likert. Menurut Sugiyono (2017) skala pengukuran merupakan kesepakatan yang digunakan sebagai acuan untuk menentukan panjang pendeknya interval yang ada dalam alat ukur sehingga alat ukur tersebut bila digunakan dalam pengukuran akan menghasilkan data.

b. Analisis Verifikatif

Analisis ferifikatif dimaksudkan untuk mengetahu keterhubungan antara variabel independen terhadap variabel dependen. Menurut Sugiyono (2017) metode

verifikatif merupakan penelitian yang bertujuan untuk mengetahui hubungan antara dua variabel atau lebih.

\section{1) Analisis \\ Berganda}

Analisis regresi

berganda untuk

menganalisis pengaruh lingkungan kerja non fisik $\left(\mathrm{X}_{1}\right)$ dan komunikasi $\left(\mathrm{X}_{2}\right)$ secara bersama-sama terhadap kinerja karyawan (Y) adalah dengan menggunakan analisis regresi berganda (Multiple regresional analisis).

2) Analisis Koefisien

\section{Korelasi}

Analisis ini bertujuan untuk mengetahui tingkat pengaruh variabel independen terhadap variabel dependen. Dalam hal ini adalah lingkungan kerja non fisik $\left(\mathrm{X}_{1}\right)$ dan komunikasi $\left(\mathrm{X}_{2}\right)$ terhadap kinerja karyawan (Y) baik secara 
parsial maupun secara simultan.

3) Analisis

Koefisien

Korelasi

Dalam

penelitian ini untuk mengetahui berapa besar prosentase kontribusi dari variabel Lingkungan kerja non fisik dan komunikasi terhadap kinerja karyawan pada PT. Bangkit Maju Bersama baik secara parsial maupun secara simultan

\section{.4) Pengujian Hipotesis}

(a) Uji t (Parsial)

Uji $\mathrm{t}$ digunakan untuk menguji signifikansi variasi hubungan antar variabel $\mathrm{X}$ dan $\mathrm{Y}$, apakah variabel $\mathrm{X}_{1}$ dan $\mathrm{X}_{2}$ benar-benar berpengaruh secara parsial terhadap variabel dependen.

(b) Uji F (Simultan)

Pengujian hipotesis simultan (Uji F) bertujuan untuk mengetahui pengaruh secara bersama-sama variabel independen terhadap variabel dependen.

\section{HASIL PENELITIAN}

DAN

PEMBAHASAN

\section{A. Uji Instrumen Penelitian}

\section{Hasil Uji Validitas}

Tabel 3 Hasil Uji Validitas Variabel

Lingkungan Kerja Non Fisik (X1)

\begin{tabular}{|c|c|c|c|}
\hline No & r hitung & r tabel & Keputusan \\
\hline KX1-1 & 0.556 & 0.254 & Valid \\
\hline
\end{tabular}

\begin{tabular}{|l|l|l|l|}
\hline KX1-2 & 0.575 & 0.254 & Valid \\
\hline KX1-3 & 0.520 & 0.254 & Valid \\
\hline KX1-4 & 0.526 & 0.254 & Valid \\
\hline KX1-5 & 0.392 & 0.254 & Valid \\
\hline KX1-6 & 0.507 & 0.254 & Valid \\
\hline KX1-7 & 0.347 & 0.254 & Valid \\
\hline KX1-8 & 0.587 & 0.254 & Valid \\
\hline KX1-9 & 0.600 & 0.254 & Valid \\
\hline KX1-10 & 0.334 & 0.254 & Valid \\
\hline
\end{tabular}

Sumber : Data primer diolah.

Dari data tabel di atas, variabel lingkungan kerja non fisik $\left(X_{1}\right)$ diperoleh nilai $r$ hitung $>\mathrm{r}$ tabel $(0,254)$. Untuk itu kuesioner yang digunakan layak untuk diolah sebagai data penelitian.

Tabel 4 Hasil Uji Validitas Variabel Komunikasi (X2)

\begin{tabular}{|c|c|c|c|}
\hline No & r hitung & r tabel & Keputusan \\
\hline KX2-1 & 0.342 & 0.254 & Valid \\
\hline KX2-2 & 0.332 & 0.254 & Valid \\
\hline KX2-3 & 0.345 & 0.254 & Valid \\
\hline KX2-4 & 0.480 & 0.254 & Valid \\
\hline KX2-5 & 0.508 & 0.254 & Valid \\
\hline KX2-6 & 0.450 & 0.254 & Valid \\
\hline KX2-7 & 0.627 & 0.254 & Valid \\
\hline KX2-8 & 0.595 & 0.254 & Valid \\
\hline KX2-9 & 0.514 & 0.254 & Valid \\
\hline KX2-10 & 0.618 & 0.254 & Valid \\
\hline \multicolumn{4}{|c|}{ Sumber Data primer diolah } \\
\hline
\end{tabular}

Sumber: Data primer diolah.

Dari data tabel di atas, variabel komunikasi $\left(\mathrm{X}_{2}\right)$ diperoleh nilai $r$ hitung $>r$ tabel $(0,254)$. Untuk itu kuesioner yang digunakan layak untuk diolah sebagai data penelitian.

Tabel 5 Hasil Uji Validitas Variabel Kinerja Karyawan (X2)

\begin{tabular}{|c|c|c|c|}
\hline No & r hitung & r tabel & Keputusan \\
\hline KY-1 & 0.342 & 0.254 & Valid \\
\hline KY-2 & 0.634 & 0.254 & Valid \\
\hline KY-3 & 0.362 & 0.254 & Valid \\
\hline KY-4 & 0.729 & 0.254 & Valid \\
\hline KY-5 & 0.558 & 0.254 & Valid \\
\hline KY-6 & 0.447 & 0.254 & Valid \\
\hline
\end{tabular}




\begin{tabular}{|r|l|l|l|}
\hline KY-7 & 0.557 & 0.254 & Valid \\
\hline KY-8 & 0.471 & 0.254 & Valid \\
\hline KY-9 & 0.387 & 0.254 & Valid \\
\hline KY-10 & 0.343 & 0.254 & Valid \\
\hline
\end{tabular}

Sumber: Data primer diolah.

Dari data tabel di atas, variabel kinerja karyawan (Y) diperoleh nilai $\mathrm{r}$ hitung $>\mathrm{r}$ tabel $(0,254)$. Untuk itu kuesioner yang digunakan layak untuk diolah sebagai data penelitian.

\section{Hasil Uji Reliabilitas}

Tabel 6. Hasil Uji Reliabilitas.

\begin{tabular}{|c|c|c|c|}
\hline Variabel & $\begin{array}{c}\text { Cronbach's } \\
\text { Alpha }\end{array}$ & $\begin{array}{c}\text { Alpha } \\
\text { Kritis }\end{array}$ & Ket \\
\hline $\begin{array}{c}\text { Lingkungan kerja } \\
\text { non fisik (X1) }\end{array}$ & 0.657 & 0.600 & Reliabel \\
$\begin{array}{c}\text { Komunikasi (X2) } \\
\text { Kinerja karyawan } \\
\text { (Y) }\end{array}$ & 0.633 & 0.600 & Reliabel \\
\hline
\end{tabular}

Sumber : Data primer diolah.

Berdasar hasil perhitungan di atas, diperoleh nilai Cronbach Alfa lebih besar dari 0.60 dan nilai $r$ bernilai positif, dengan demikian maka butir pernyataan variabel lingkungan kerja non fisik, komunikasi dan kinerja karyawan dinyatakan reliabel.

\section{PENGUJIAN ASUMSI KLASIK}

\section{Uji Normalitas}

Uji normalitas dilakukan untuk menguji apakah dalam model regresi, variabel dependen dan variabel independen berdistribusi normal atau berdistribusi tidak normal. Berikut ini hasil uji normalitas dengan alat uji Grafik P-P Plot, sebagai berikut:

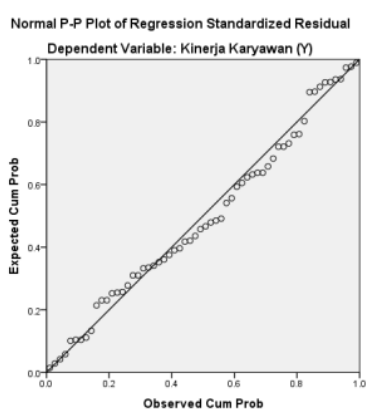

Pada gambar di atas dapat dilihat bahwa grafik normal probability plot menunjukkan pola grafik yang normal. Hal ini terlihat dari titik yang menyebar disekitar garis diagonal dan penyebarannya mengikuti garis diagonal. Oleh karena ini dapat disimpulkan bahwa model regresi memenuhi asumsi normalitas.

\section{Uji Multikonilieritas}

Uji mutlikolinearitas dipergunakan untuk mengetahui antar variabel bebas tidak memiliki multikolinearitas atau tidak memiliki hubungan korelas. Model regresi yang baik seharusnya tidak terjadi korelasi di antara variabel independen. Uji multikolinearitas dilakukan dengan melihat nilai Tolerance Value dan Variance Inflation Factor (VIF).

Hasil pengujian pada tabel di atas, nilai tolerance masingmasing variabel bebas yaitu 0,654 $<$ 1,0 dan nilai Variance Inflation Factor (VIF) sebesar 1,528 < 10, dengan demikian model regresi ini tidak ada multikolinearitas.

\section{Uji Autokorelasi}

Uji

Autokorelasi dimaksudkan untuk mengetahui ada atau tidaknya penyimpangan korelasi antar anggota sampel. Pengujian dilakukan dengan alat uji Darbin-Watson (DW test). Adapun hasil pengujiannya 
diperoleh nilai Durbin-Watson sebesar 2.257 yang berada diantara interval $1.550-2.460$. Dengan demikian model regresi yang digunakan pada penelitian ini tidak ada autokorelasi.

\section{Uji Heteroskesdastisitas}

Pengujian heteroskedastisitas dimaksudkan untuk menguji apakah dalam sebuah model regresi terjadi ketidaksamaan varians residual. Dalam penelitian ini digunakan uji grafik scaterplot dimana hasilnya titik-titik pada grafik scatterplot tidak mempunyai pola penyebaran yang jelas atau tidak membentuk pola-pola tertentu dan titik-titik tersebut menyebar di atas dan dibawah angka 0 pada sumbu $\mathrm{Y}$, dengan demikian hal ini menunjukkan bahwa tidak terdapat gangguan heteroskedastisitas pada model regresi sehingga model regresi ini layak dipakai

\section{HASIL ANALISIS DATA}

Pengujian ini dimaksudkan untuk menunjukkan hasil dari pengujian atas variabel lingkungan kerja non fisik dan komunikasi terhadap kinerja karyawan. Hasil analisisnya sebagai berikut:

\section{Analisis Regresi Berganda}

Analisis regresi berganda dimaksudkan untuk mengetahui seberapa besar pengaruh variabel lingkungan kerja non fisik $\left(\mathrm{X}_{1}\right)$ dan komunikasi $\left(\mathrm{X}_{2}\right.$ terhadap kinerja karyawan (Y). Berdasarkan perhitungan regresi linier berganda diperoleh hasil sebagai berikut:

Tabel 7. Hasil Uji Regresi Linier Berganda

Coefficients

\begin{tabular}{|c|c|c|c|c|c|}
\hline & \multicolumn{2}{|c|}{$\begin{array}{c}\text { Unstandardized } \\
\text { Coefficients }\end{array}$} & $\begin{array}{c}\text { Standardized } \\
\text { Coefficients }\end{array}$ & & \\
\cline { 2 - 4 } Model & & Std. Error & Beta & & Sig. \\
\hline (Constant) & 9.210 & 3.806 & & 2.420 & .019 \\
Lingkungan kerja & .396 & .106 & .424 & 3.749 & .000 \\
non fisik (X1) & & .110 & .387 & 3.426 & .001 \\
Komunikasi (X2) & .377 & .10 & & & \\
\hline
\end{tabular}

Sumber : Data Primer diolah

Berdasarkan hasil

perhitungan pada tabel di atas, diperoleh bentuk persamaan regresi standardized sebagai berikut: $Y=9,210+0,396 X_{1}+$ $0,377 \mathrm{X}_{2}$. Dari persamaan di atas maka dapat disimpulkan sebagai berikut:

1) Nilai konstanta sebesar 9,210 diartikan bahwa jika variabel Lingkungan Kerja Non Fisik $\left(\mathrm{X}_{1}\right)$ dan Komunikasi $\left(\mathrm{X}_{2}\right)$ tidak ada maka telah terdapat nilai Kinerja Karyawan (Y) sebesar 9,210 point.

2) Nilai 0,396 diartikan apabila konstanta tetap dan tidak ada

perubahan pada variabel Komunikasi $\left(\mathrm{X}_{2}\right)$, maka setiap perubahan 1 unit pada variabel Lingkungan Kerja Non Fisik $\left(\mathrm{X}_{1}\right)$ akan mengakibatkan terjadinya perubahan pada Kinerja Karyawan (Y) sebesar 0,396 point.

3) Nilai 0,377 diartikan apabila konstanta tetap dan tidak ada perubahan pada variabel Lingkungan Kerja Non Fisik $\left(\mathrm{X}_{1}\right)$, maka setiap perubahan 1 unit pada variabel Komunikasi $\left(\mathrm{X}_{2}\right)$ akan mengakibatkan terjadinya perubahan pada 
Kinerja Karyawan (Y) sebesar 0,377 point.

4)

\section{Analisis Koefisien Korelasi}

Analisis koefisien

korelasi dimaksudkan untuk mengetahui tingkat kekuatan hubungan dari variabel bebas terhadap variabel terikatnya. Adapun hasil pengolahan data dapat dijelaskan sebagai berikut:

Tabel 8. Hasil Uji Koefisien Korelasi Pengaruh Lingkungan kerja non fisik (X1) Terhadap Kinerja karyawan (Y) Correlations ${ }^{\mathrm{b}}$

\begin{tabular}{|c|c|c|c|}
\hline & & $\begin{array}{c}\text { Lingkungan kerja } \\
\text { non fisik (X1) }\end{array}$ & $\begin{array}{c}\text { Kinerja karyawan } \\
(\mathrm{Y})\end{array}$ \\
\hline $\begin{array}{l}\text { Lingkungan kerja non fisik } \\
\text { (X1) }\end{array}$ & $\begin{array}{l}\text { Pearson Correlation } \\
\text { Sig. (2-tailed) }\end{array}$ & 1 & $\begin{array}{c}.652^{* * *} \\
.000\end{array}$ \\
\hline Kinerja karyawan $(\mathrm{Y})$ & $\begin{array}{l}\text { Pearson Correlation } \\
\text { Sig. (2-tailed) }\end{array}$ & $\begin{array}{l}.652^{* * *} \\
.000\end{array}$ & 1 \\
\hline
\end{tabular}

Sumber: Data Primer diolah

.Berdasarkan hasil pada lingkungan kerja non fisik (X1) tabel di atas diperoleh nilai korelasi sebesar 0,652 . Hal ini menunjukkan bahwa variabel secara parsial memiliki tingkat hubungan yang kuat terhadap kinerja karyawan (Y).

Tabel 9. Hasil Uji Koefisien Korelasi Pengaruh Komunikasi (X2) Terhadap Kinerja karyawan (Y)

Correlations $^{b}$

\begin{tabular}{|cc|c|c|}
\hline & & $\begin{array}{c}\text { Lingkungan kerja non } \\
\text { fisik (X1) }\end{array}$ & Kinerja karyawan (Y) \\
\hline Komunikasi (X2) & Pearson Correlation & 1 & $.637^{* *}$ \\
& Sig. (2-tailed) & & .000 \\
\hline $\begin{array}{c}\text { Kinerja karyawan } \\
\text { (Y) }\end{array}$ & $\begin{array}{c}\text { Pearson Correlation } \\
\text { Sig. (2-tailed) }\end{array}$ & $.637^{* * *}$ & 1 \\
\hline
\end{tabular}

Sumber: Data Primer diolah

Berdasarkan hasil pada tabel di atas diperoleh nilai korelasi sebesar 0,637. Hal ini menunjukkan bahwa variabel komunikasi (X2) secara parsial memiliki tingkat hubungan yang kuat terhadap kinerja karyawan (Y).

Tabel 10. Hasil Uji Koefisien Korelasi Pengaruh Lingkungan kerja non fisik

(X1) dan Komunikasi (X2) Secara Simultan Terhadap Kinerja karyawan (Y)

Model Summary

\begin{tabular}{|c|c|c|c|c|}
\hline Model & $\mathrm{R}$ & $\begin{array}{c}\mathrm{R} \\
\text { Square }\end{array}$ & $\begin{array}{c}\text { Adjuste } \\
\text { d R } \\
\text { Square }\end{array}$ & $\begin{array}{l}\text { Std. Error of } \\
\text { the Estimate }\end{array}$ \\
\hline 1 & $.723^{\mathrm{a}}$ & .523 & .506 & 2.423 \\
\hline
\end{tabular}

Sumber : Data Primer diolah
Berdasarkan hasil pada tabel di atas diperoleh nilai korelasi sebesar 0,723. Hal ini menunjukkan bahwa variabel lingkungan kerja non fisik (X1) dan komunikasi (X2) secara simultan memiliki tingkat hubungan yang kuat terhadap kinerja karyawan (Y).

\section{Analisis Koefisien Determinasi}

Tabel 11. Hasil Uji Koefisien Determinasi Pengaruh Lingkungan kerja non fisik

(X1) Terhadap Kinerja karyawan (Y) Model Summary

\begin{tabular}{|l|c|r|r|r|}
\hline & & $\mathrm{R}$ & $\begin{array}{c}\text { Adjuste } \\
\mathrm{d} \mathrm{R}\end{array}$ & Std. Error of \\
Model & $\mathrm{R}$ & Square & Square & the Estimate \\
\hline 1 & $.652^{\mathrm{a}}$ & .425 & $.40,55$ & 2.638 \\
\hline
\end{tabular}


Berdasarkan hasil pada tabel di atas diperoleh nilai $R$ Square sebesar 0,425. Hal ini menunjukkan bahwa pengaruh lingkungan kerja non fisik terhadap kinerja karyawan sebesar $42,5 \%$,

Tabel 12. Hasil Uji Determinasi Pengaruh Komunikasi (X2) Terhadap Kinerja karyawan (Y)

Model Summary

\begin{tabular}{|l|l|r|r|r|}
\hline Model & $\mathrm{R}$ & $\begin{array}{c}\mathrm{R} \\
\text { Square }\end{array}$ & $\begin{array}{c}\text { Adjuste } \\
\mathrm{d} \mathrm{R} \\
\text { Square }\end{array}$ & $\begin{array}{c}\text { Std. Error of } \\
\text { the Estimate }\end{array}$ \\
\hline 1 & $.637^{\mathrm{a}}$ & .405 & .395 & 2.682 \\
\hline
\end{tabular}

Sumber : Data Primer diolah

Berdasarkan hasil pada tabel di atas, diperoleh nilai koefisien determinasi $(R$ Square) sebesar 0,405. Hal ini menunjukkan bahwa pengaruh komunikasi secara parsial terhadap kinerja karyawan sebesar 40,5\%.

Tabel 13. Hasil Uji Koefisien Determinasi Pengaruh Lingkungan kerja non fisik (X1) dan Komunikasi (X2) Terhadap Kinerja karyawan (Y) Model Summary

\begin{tabular}{|l|c|r|r|r|}
\hline Model & $\mathrm{R}$ & $\begin{array}{c}\mathrm{R} \\
\text { Square }\end{array}$ & $\begin{array}{c}\text { Adjuste } \\
\mathrm{d} \mathrm{R} \\
\text { Square }\end{array}$ & $\begin{array}{l}\text { Std. Error of } \\
\text { the Estimate }\end{array}$ \\
\hline 1 & $.723^{\mathrm{a}}$ & .523 & .506 & 2.423 \\
\hline
\end{tabular}

Sumber : Data Primer diolah

Berdasarkan hasil pada tabel di atas dapat dilihat bahwa nilai koefisien determinasi $(R$ Square) sebesar 0,52,3 atau $52,3 \%$. Hal ini menunjukkan bahwa pengaruh lingkungan kerja non fisik (X1) dan komunikasi (X2) secara simultan terhadap kinerja karyawan (Y) adalah sebesar $47,7 \%$, sedangkan sisanya sebesar 52,4\% dipengaruhi oleh faktor lain.

\section{Pengujian Hipotesis}

\section{a. Uji Hipotesis Parsial (Uji t)}

Hipotesis Pertama:

Terdapat pengaruh positif dan signifikan antara lingkungan kerja non fisik terhadap kinerja karyawan.

Tabel 14. Uji Hipotesis Lingkungan kerja non fisik (X1) Terhadap Kinerja karyawan (Y) Coefficients $^{\mathbf{a}}$

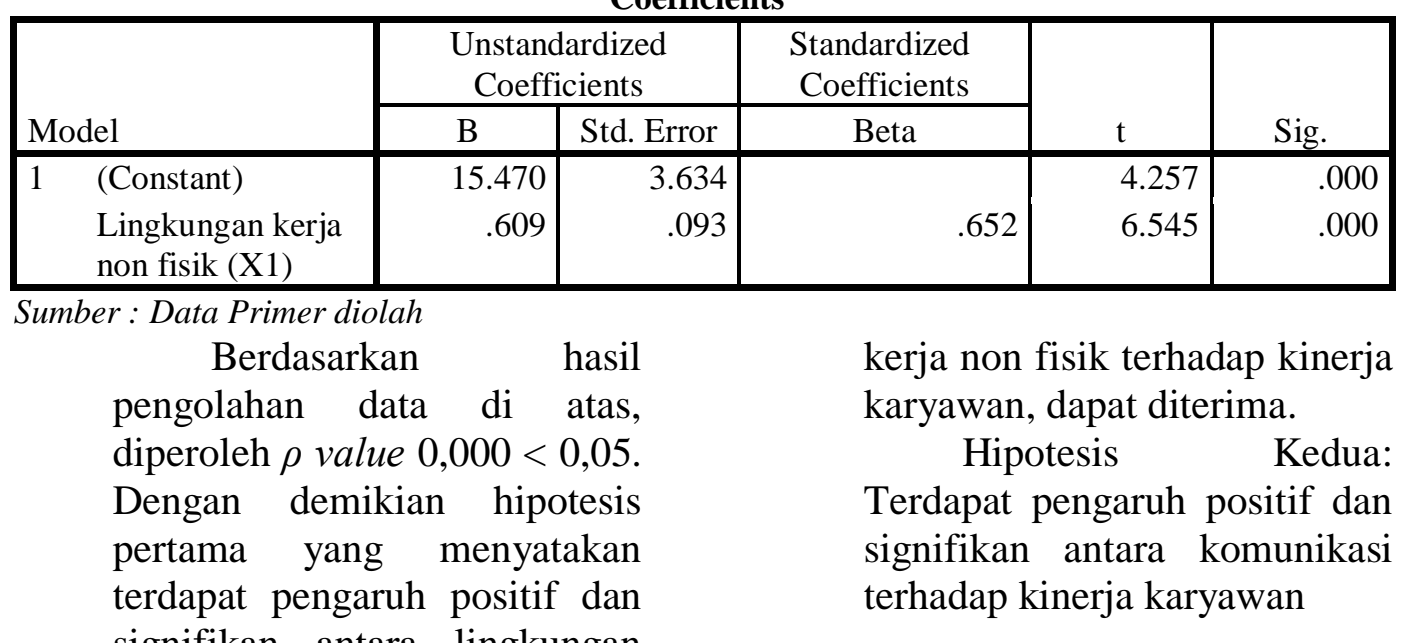


Tabel 15. Pengujian Hipotesis Variabel Komunikasi (X2) Terhadap Kinerja karyawan (Y) Coefficients $^{\mathrm{a}}$

\begin{tabular}{|c|c|c|c|c|c|}
\hline \multirow[b]{2}{*}{ Model } & \multicolumn{2}{|c|}{$\begin{array}{l}\text { Unstandardized } \\
\text { Coefficients }\end{array}$} & \multirow{2}{*}{$\begin{array}{c}\begin{array}{r}\text { Standardized } \\
\text { Coefficients }\end{array} \\
\text { Beta }\end{array}$} & \multirow[b]{2}{*}{$\mathrm{t}$} & \multirow[b]{2}{*}{ Sig. } \\
\hline & B & Std. Error & & & \\
\hline $\begin{array}{cc}1 & \text { (Constant) } \\
\text { Komunikasi (X2) }\end{array}$ & $\begin{array}{c}15.263 \\
.620\end{array}$ & $\begin{array}{c}3.814 \\
.099\end{array}$ & .637 & $\begin{array}{l}4.002 \\
6.288\end{array}$ & $\begin{array}{l}.000 \\
.000\end{array}$ \\
\hline
\end{tabular}

Sumber : Data Primer diolah

Berdasarkan hasil pengolahan data di atas, diperoleh $\rho$ value $0,000<0,05$. Dengan demikian hipotesis kedua yang menyatakan bahwa terdapat pengaruh positif dan signifikan antara komunikasi terhadap kinerja karyawan, dapat diterima.

Tabel 22. Pengujian Hipotesis Secara Simultan

\section{b. Uji Hipotesis Secara Simultan (Uji F)}

Hipotesis Ketiga:

Terdapat pengaruh positif dan signifikan antara lingkungan kerja non fisik (X1) dan komunikasi (X2) secara simultan terhadap kinerja karyawan. Hasil ujinya yaitu:

\begin{tabular}{|cc|c|c|c|c|c|}
\hline \multicolumn{1}{|c|}{} & Sum of & & & & \\
& Model & Squares & df & Mean Square & F & Sig. \\
\hline 1 & Regression & 366.983 & 2 & 183.492 & 31.252 & $.000^{\mathrm{b}}$ \\
& Residual & 334.667 & 57 & 5.871 & & \\
& Total & 701.650 & 59,5 & & & \\
\hline
\end{tabular}

Sumber : Data Primer diolah

Berdasarkan hasil uji di atas, diperoleh $\rho$ value $0,000<$ 0,05, dengan demikian hipotesis ketiga yang menyatakan terdapat pengaruh positif dan signifikan antara lingkungan kerja non fisik dan komunikasi secara simultan terhadap kinerja karyawan diterima.

\section{DAFTAR PUSTAKA}

Bilson, Simamora, 2014, "Panduan Riset Prilaku Konsumen", Jakarta, PT. Gramedia Pustaka.

Gerry, Dessler, 2000 "Human Resources Management", Prenticehall, International Inc, London. Hasibuan, 2012, "Manajemen Sumber Daya Manusia”, Jakarta, Haji Masagung.
Imam,Ghozali, 2011 "Aplikasi Analisis Multivariate dengan Program SPSS", Semarang, Edisi Kelima, Badan Penerbit Undip.

Levy, P.E, 2000, “Industrial Organization Psycology", Miffilin Company Boston Houghton.

Miftah, Thoha, 2007, "Kepemimpinan Dalam Manajemen", Jakarta, Edisi Pertama, PT. Raja Grafindo.

Nachrowi Djalal, Nachrowidan Hardius Usman, 2010, "Teknik Pengambilan Keputusan”. Jakarta, Penerbit PT. Grasindo. Nawawi, 2006, "Sumber Daya Manusia untuk Bisnis yang Kompetitif", Jakarta, Prehalindo. 
Robbins, S. \& Judge, T, 2008, "Organizational Behavior", Edisi keduabelas, , Prentice Hall..

Safroni, Ladzi, 2012, "Manajemen dan Reformasi Pelayanan Publik dalam Konteks Birokrasi Indonesia", Surabaya.

Salam, Darma Setyawan, 2007, "Manajemen Pemerintahan Indonesia", Jakarta, Djambatan.

Sarwono, Jonathan, 2012, "Metode Penelitian Kuantitatif Dan Kualitatif", Yogyakarta, Graha Ilmu.

Singgih Santoso, 2010, "SPSS Statistik Parametik" Jakarta, Cetakan Kedua, PT. Elek Media.

Sondang P, Siagian, 2010, "Kiat Meningkatkan Produktivitas Kerja”, Jakarta, PT. Rineka Cipta.

Sugiyono, 2017 "Metode Penelitian Kuantitatif Kualitatif dan $R \&$
D”, Bandung, Penerbit CV. Alfabeta.

Suharsimi Arikunto, 2010 "Prosedur Penelitian Suatu Pendekatan Praktek", Jakarta. PT. Rineka Cipta.

Sutrisno,Edy, 2012, "Sumber Daya Manusia”, Surabaya, PT. Gramedia.

Umar, Husen, 2008, "Riset Pemasaran Dan Perilaku Konsumen”, Jakarta, PT. Gramedia Pustaka Utama.

Wibowo, 2009, "Manajemen Kinerja”, Jakarta, PT. Raja Grafindo Persada.

Windy Aprilia dan Gunasti Hudiwinarsih, 2012, "Teori Kompensasi, Motivasi dan Komitmen Organisasi”, Jakarta, Gramedia.

Wirawan, 2009, “.Evaluasi Kinerja Sumber Daya Manusia (Teori Aplikasi dan Penelitian)". Jakarta, Salemba Empat. 